\title{
Removal of cadmium ions from aqueous solution using very small ionic liquids to water ratio without metal chelator and pH modifications
}

\author{
Atakilt Abebe $^{1 *}$, Sossina Tilahun ${ }^{1}$, Mikias Mesfine ${ }^{1}$ and Minaleshewa Atlabachew ${ }^{1}$ \\ ${ }^{1}$ Department of Chemistry, Bahir Dar University, Bahir Dar, 79, Ethiopia
}

\begin{abstract}
Solvent extraction is an energy-efficient technology which uses two immiscible phases. In this regard, solvents like hydrophobic 1-butyl-3-methylimidazolium hexafluorophosphate based ionic liquids have been used. The hydrophilicity of the metal ions is a challenge to use this method. Coordinating the metal ions by ligands, lowering the $\mathrm{pH}$ of the aqueous phase, modifying the ionic liquid itself in such a way that it can coordinate with the metal ions, employment of large ionic liquid to aqueous phase ratio (minimum of 1:1) were also the attempts made to improve the distribution coefficient of the ionic liquids. All these efforts are problematic in hindering the applications of ionic liquids in extraction. In this report, the extraction efficiencies of ionic liquids $\left(\mathrm{C}_{4} \mathrm{mim}\right]\left[\mathrm{PF}_{6}\right],\left[\mathrm{C}_{6} \mathrm{mim}\right]\left[\mathrm{PF}_{6}\right],\left[\mathrm{C}_{8} \mathrm{mim}\right]\left[\mathrm{PF}_{6}\right]$ and $\left.\left[\mathrm{C}_{10} \mathrm{mim}\right]\left[\mathrm{PF}_{6}\right]\right)$ from water samples containing $\mathrm{Cd}^{2+}$ using very small ionic liquid to water ratio (1:6 and 1:12) from a solution of concentrations $0.005 \mathrm{mg} / \mathrm{L}$ with out using any coordinating agent as an extractant and the need of changing the $\mathrm{pH}$ are disclosed. While ionic liquids to aqueous phase ratio $1: 12$ demonstrated extraction efficiencies of $75 \%, 83.75 \%, 87.50 \%$ and $100 \%$, respectively; the $1: 6$ ratio extracted $87.50 \%, 100 \%, 100 \%$ and $100 \%$, respectively which shows suitability of the later ratio for better extraction. Moreover, the recyclabilities of $\left[\mathrm{C}_{6} \mathrm{mim}\right]\left[\mathrm{PF}_{6}\right]$ and $\left[\mathrm{C}_{8} \mathrm{mim}\right]\left[\mathrm{PF}_{6}\right]$ was investigated and the result showed that they can be used at least for five cycles. A Linear calibration curve with good coefficient of determination was obtained during the analysis for determination of the metal in the extracts.
\end{abstract}

Key words: Cadmium(II), Ionic Liquids, Extraction, Recyclability, Small Ionic Liquid to Water Ratio.

DOI: http://dx.doi.org/10.4314/ejst.v10i1.4

\section{INTRODUCTION}

The concentration of toxic heavy metals in natural water bodies has been increasing (Motsi et al., 2009; Hernandez et al., 2010; Pinto et al., 2011). Heavy metals such as cadmium, zinc, lead, chromium, nickel, copper, vanadium, platinum, silver, and titanium are generated in electroplating, electrolysis depositions, conversion coating, and anodizing-cleaning, milling, and etching industries. Significant amount of heavy metals wastes like tin, lead, and nickel result from printed circuit board (PCB) manufacturing. Wood processing industries where a chromated copper-arsenate wood treatment produces arsenic containing wastes; inorganic pigment manufacturing producing pigments contain chromium compounds and cadmium sulfide; petroleum refining generates conversion catalysts contaminated with nickel, vanadium, and chromium; and photographic operations producing film with high concentrations of silver and ferrocyanide. All of these generators produce a large quantity of wastewaters, residues, and sludge that can be categorized as hazardous wastes requiring extensive waste treatment (Gunatilake, 2015). Consequently, they are accumilated in food chains that pose a threat to human health, animals and plants and ecological systems (Manahan, 2011;

*Corresponding author: atakiltabebe1@gmail.com

(C) This is an Open Access article distributed under the terms of the Creative Commons Attribution License (http://creativecommons.org/licenses/CC BY4.0). 
Gunatilake, 2015). Therefore, efficient treatment of water by removing toxic heavy metals has been one of the major concerns. A number of specialized processes have been developed for the removal of metals from waste discharges. These include chemical precipitation ( $\mathrm{Ku}$ and Jung, 2001), coagulation/flocculation (Samrani et al., 2008), ion exchange (Kang et al., 2004), electrochemical operations (Wang et al., 2007), biological operations (Pavasant et al., 2006), adsorption (Fu and Wang, 2011), filtration, and membrane processes (Landaburu-Aguirre et al., 2009). The choice of method is based on the concentration of the metal ions in the solution and the cost of treatment (Richardson and Harker, 2002). Solvent extraction is an energy-efficient technology which uses two immiscible phases (conventionally an organic phase and an aqueous phase) (Alonso et al., 2006; de los Ríos et al., 2009). In this regard, different solvents have been used in the recovery and separation of metals from aqueous solutions. One way of removing metal ions from an aqueous phase is by dissolving extractants such as di(2-ethylhexyl) phosphoric acid, tris(2ethylhexyl)amine, liquid phosphine oxides in an organic solvent such as kerosene and toluene. One disadvantage of this method of extraction is the loss of organic solvents via volatilization, which has a detrimental impact on the environment and human health (Lancaster, 2010). Consequently, different attempts have been implemented to minimize these draw backs. Replacement of the volatile organic solvents by non-volatile ones such as ionic liquids (ILs) is among such efforts (Wei et al., 2003; Domańska and Zhao, 2005; Platzer et al., 2015).

Ionic liquids (ILs) are low temperature melting salts (below $100{ }^{\circ} \mathrm{C}$ ) (Villar-Garcia et al., 2012; Atakilt Abebe et al., 2013). They are fundamentally different from salt solutions and molecular solvents. They are well characterized by unique properties, such as negligible vapor pressure, good thermal stability, tunable viscosity and designed miscibility with water and organic solvents, good extractability for various organic compounds as well as possession of cavities in their three dimensional microstructure (Huang et al., 2005). For ionic liquids to be effectively used as solvents in liquid-liquid extractions, the knowledge of the mutual solubilities between ILs and the second liquid phase is fundamental. The mutual solubilities of water and imidazolium-based ILs were extensively studied and reported elsewhere. The results indicate that mutual solubilities are primarily defined by the anion followed by the cation alkyl side chain length. Methylimidazolium based ILs with the anion $\mathrm{PF}_{6}$ are totally hydrophobic and the mole fractions of water in $\left[\mathrm{C}_{4} \mathrm{mim}\right]\left[\mathrm{PF}_{6}\right], \quad\left[\mathrm{C}_{6} \mathrm{mim}\right]\left[\mathrm{PF}_{6}\right], \quad\left[\mathrm{C}_{8} \mathrm{mim}\right]\left[\mathrm{PF}_{6}\right]$ and $\left[\mathrm{C}_{10} \mathrm{mim}\right]\left[\mathrm{PF}_{6}\right]$ at $298 \mathrm{~K}$ are reported to be $0.23 \%$, $0.18 \%, 0.16 \%$ and $0 \%$, respectively (Freire et al., 2007).

At present, ILs mostly used in extraction of metal ions from aqueous phase are the hydrophobic 1-butyl-3-methylimidazolium hexafluorophosphate, $\left[\mathrm{C}_{4} \operatorname{mim}\right]\left[\mathrm{PF}_{6}\right]$, or 1-hexyl-3-methylimidazolium hexafluorophosphate, $\left[\mathrm{C}_{6} \mathrm{mim}\right]\left[\mathrm{PF}_{6}\right]$ or other ILs with hexafluorophosphate, $\mathrm{PF}_{6}^{-}$, or bis $\{$ (trifluoromethyl)sulfonyl $\}$ imide, $\quad \mathrm{NTf}_{2}^{-}$, anions (Visser et al., 2001; Wei et al., 2003; Dietz, 2006). Charged metal ions are usually insoluble in hydrophobic ionic liquids (IL), so extractants are necessary in the IL's phase just as in organic solvent (Villemin and Didi, 2014). Therefore, researchers exerted different efforts to increase the distribution coefficients of the ILs by increasing the metal's hydrophobicity. This included employment of extractants to form complexes with metal ions (Wei et al., 2003), grafting coordinating agents 
on the cations of the ILs themselves (Visser et al., 2002), modifying the $\mathrm{pH}$ condition using hydrochloric acid solutions (Wei et al., 2003; Hernandez et al., 2010). Large IL to water ratio quantity (1:1) was also employed (Earle and Seddon, 2000; Sereshti et al., 2014). Moreover, the extraction activities using ionic liquids were carried out from water samples containing far greater concentrations (Hernandez et al., 2010) than the metal ions found in real samples (Xu et al., 2010).

The addtional steps in modifying the ILs were found to incur additional synthetic cost and elongated time. Moreover, the use of large IL (which are expensive) (Abbott et al., 2004; Hayyan et al., 2013) to aqueous phase ratio makes the employment of these types of ILs impractical.

There is no literature report on the extraction of toxic heavy metals in general and $\mathrm{Cd}^{2+}$ in particular minimizing the above problemes combined. Taking this gap as an opportunity, herein, we investigate the extraction efficiencies of ILs, namely $\left[\mathrm{C}_{4} \mathrm{mim}\right]\left[\mathrm{PF}_{6}\right], \quad\left[\mathrm{C}_{6} \mathrm{mim}\right]\left[\mathrm{PF}_{6}\right]$, $\left[\mathrm{C}_{8} \mathrm{mim}\right]\left[\mathrm{PF}_{6}\right]$ and $\left[\mathrm{C}_{10} \mathrm{mim}\right]\left[\mathrm{PF}_{6}\right]$, from water samples containing $\mathrm{Cd}^{2+}$ using very small IL to water ratio $(1: 12$ and $1: 6)$ from a solution of concentrations nearly similar to its existence in the real samples with out using any coordinating agent as an extractant and the need of changing the $\mathrm{pH}$. Moreover, the extent at which ILs can be used repeatedly as much as possible were investigated. These facts reported here may reduce the concern about the high cost of the solvent jointly with the problems associated with their disposal. Thus, the scientific and industrial community may be encouraged to be benefited from the attractive numerous properties of ILs from the implementation of this technology in research and production.

\section{EXPERIMENTAL}

\section{Materials}

The chemicals used in this investigation were 1-Methylimmidazole, 1-chlorobutane, 1-bromohexane, 1-bromooctane and 1-bromodecane (Fairfield, OH, USA), potassium hexafluorophosphate (Rockford, IL, USA), acetone, ethyl acetate, diethyl ether, paraffin, tetra hydrated cadmium nitrate were obtained from Sigma-Aldrich-Fluka Chemical Co, Madrid, Spain. ${ }^{1} \mathrm{H}$ NMR and ${ }^{13} \mathrm{C}$ NMR spectra were recorded on $400 \mathrm{MHz}$ NMR spectrometer (Bruker Avance 400 NMR spectrometer at $400 \mathrm{MHz}$, Germany) by dissolving approximately $10 \mathrm{~mL}$ of the sample in $\mathrm{CDCl}_{3}$

Inductively coupled plasma optical emission (ICP-OES) spectroscopy (“ULTIMA-2" HORIBA scientific, Japan) was employed in the investigation of the extraction efficiency. The operating parameters of ULTIMA-2 ICP- OES spectrometer for the analysis of $\mathrm{Cd}^{+2}$ is summarized as in the table below (Table 1).

\section{Synthesis of the ionic liquids (ILs)}

Three new ILs were synthesized and purified according to reported procedures (Bonhote et al., 1996). The ILs were synthesized in two steps. The first step involved synthesis of ILs with halide anions and the second step, exchange of the halide anions with hexafluorphosphate, $\mathrm{PF}_{6}^{-}$and characterized using ${ }^{1} \mathrm{H}$ and ${ }^{13} \mathrm{C}$ NMR.

\section{Sample preparation for extraction process}

A $0.005 \mathrm{mg} / \mathrm{L} \mathrm{Cd}^{2+}$ solution was prepared following appropriate dilution from $183 \mathrm{mg} / \mathrm{L}$ stock solution which was prepared by dissolving $0.5 \mathrm{~g}$ of $\mathrm{Cd}\left(\mathrm{NO}_{3}\right)_{2} \cdot 4 \mathrm{H}_{2} \mathrm{O}$ in distilled water. 
Table 1. The operating parameters of ULTIMA-2 ICP- OES for the analysis of $\mathrm{Cd}^{+2}$.

\begin{tabular}{ll}
\hline Parameters & Value \\
\hline RF generator plasma power $(\mathrm{W})$ & 1500 \\
Plasma gas flow rate ( L/min) & PL1 \\
Auxiliary gas flow rate (L/min) & 0.3 \\
Nebulizer or carrier gas flow rate (L/min) & 0.53 \\
Nebulizer pressure & 1.76 \\
Spectra line ( analytical wave length) $(\mathrm{nm})$ & 228.802 \\
Sample replicates & 3 \\
Maximum integration times (sec.) & 5 \\
\hline
\end{tabular}

\section{Extraction of $\mathrm{Cd}^{2+}$ from the aqueous phase by ILs}

Traditionally, large IL to water ratio (minimum of $1: 1)$ is been reported for the extraction of metal ions from aqueous phase (Earle and Seddon, 2000; Sereshti et al., 2014). However, ILs are expensive that makes their application for this purpose expensive. To fill this gap, smaller IL to water ratios (1:6 and 1:12) were used to remove the metal ions which significantly minimizes the cost of extraction.

\section{Extraction using 1:6 IL to aqueous phase ratio}

Exactly $6 \mathrm{~mL}$ of a $0.005 \mathrm{mg} / \mathrm{L}$ cadmium ion $\left(\mathrm{Cd}^{2+}\right)$ solution was transferred to a $25 \mathrm{~mL}$ conical- flask, to which $1 \mathrm{~mL}$ IL ([ $\left.\mathrm{C}_{4} \mathrm{mim}\right]$ $\left.\left[\mathrm{PF}_{6}\right]\right)$ was added and two phases were formed. The mixture was shaken mechanically for $1 \mathrm{~h}$ at room temperature and then allowed to stand to attain equilibrium and phase separation. Then, $4 \mathrm{~mL}$ aqueous phase was taken from the mixture and diluted to $25 \mathrm{~mL}$ using distilled water. The concentration of cadmium ion that was left in the aqueous phase (not extracted by the IL) was determined by ICP-OES. The IL phase was placed in a clean and dry beaker, to which $10 \mathrm{~mL}, 69-72$ $\% \mathrm{HNO}_{3}$ was added and the content was heated gently until a few drops remained in the beaker. The latter step was repeated three times until the entire organic portion was removed. Then the residue was dissolved and diluted using distilled water in a $25 \mathrm{~mL}$ volumetric flask. Similar procedure was followed for the remaining ILs $\left(\left[\mathrm{C}_{6} \mathrm{mim}\right]\left[\mathrm{PF}_{6}\right], \quad\left[\mathrm{C}_{8} \mathrm{mim}\right]\left[\mathrm{PF}_{6}\right], \quad\right.$ and $\quad\left[\mathrm{C}_{10} \mathrm{mim}\right]$ $\left.\left[\mathrm{PF}_{6}\right]\right)$. For the control solution, exactly $4 \mathrm{~mL}$ of $0.005 \mathrm{mg} / \mathrm{L}$ of $\mathrm{Cd}^{2+}$ solution was taken, diluted to $25 \mathrm{~mL}$ using distilled water and analyzed by ICP-OES. Each experiment was repeated three times. The precision of the method was evaluated by calculating standard deviation (SD) and relative standard deviation (RSD) of the replicate measurements. For all the data obtained, the $\%$ RSD values were below 5\% which signifies the repeatability of the procedure.

The extraction ability of the ILs from the aqueous phase was investigated by measuring the concentration of $\mathrm{Cd}^{2+}$ in the aqueous phase before and after the extraction process and in the ILs after the extraction. 


\section{Extraction using 1:12 IL to aqueous phase ratio}

Similar procedure as above was employed except that $0.5 \mathrm{~mL}$ of IL was used as extractant.

\section{Recyclability of the ILs}

The reusability of the ionic liquid was evaluated by taking solution of cadmium metal ion. The same ionic liquid was used repeatedly after stripping $\mathrm{Cd}^{+2}$ from the ionic liquid after each extraction step was carried out. In this case, $1 \mathrm{~mL}$ of [ $\left.\mathrm{C}_{6} \mathrm{mim}\right]$ $\left[\mathrm{PF}_{6}\right]$ was transferred to $25 \mathrm{~mL}$ conical flask and mixed with $6 \mathrm{~mL}$ aqueous phase containing 1.2 $\mathrm{mg} / \mathrm{L}$ cadmium metal ion. It was shaken for 1 hr and left to stand for 40 minute. The cadmium metal ion concentration in the aqueous phase was determined. Then after $3 \mathrm{~mL}$ of $0.1 \mathrm{M} \mathrm{HNO}_{3}$ acid solution was added to the ionic liquid phase and shaken to strip the $\mathrm{Cd}^{+2}$ from ionic liquid. The acid was removed from the IL washing with $5 \mathrm{~mL}$ distilled water three times and then extraction was carried out as above. The extraction and stripping was repeated five times. The same procedure was followed for $\left[\mathrm{C}_{8} \mathrm{mim}\right]\left[\mathrm{PF}_{6}\right]$.

\section{Calibration of the ICP-OES instrument}

The ICP-OES was calibrated using standard solutions of cadmium ion concentrations indicated in Table 2. The results clearly show that the calibration curve with good coefficient of determination was obtained during the analysis.

Table 2. Working standards of the calibration curve for determinations of $\mathrm{Cd}^{2+}$ using ICP-OES.

\begin{tabular}{llll}
\hline Standards & Concentration $(\boldsymbol{\mu g} / \mathbf{m L})$ & Intensity & Regression equation \\
\hline 1 & 0.1 & 435460.00 & \\
2 & 1.0 & 435463.57 & \\
3 & 2.0 & 436357.43 & \\
4 & 3.0 & 437106.78 & \\
5 & 4.0 & 438037.02 & $\mathrm{Y}=434630.3+843.7 \mathrm{X}$ \\
6 & 5.0 & 438842.40 & \\
7 & 6.0 & 439692.41 & \\
\hline
\end{tabular}

\section{RESULTS AND DISCUSSION}

\section{Characterization of the ILs}

Nuclear magnetic resonance (NMR) spectroscopy is one of the powerful techniques by which the synthesis and purity of ILs is investigated. Therefore, proton $\left({ }^{1} \mathrm{H}\right)$ and carbon $\left({ }^{13} \mathrm{C}\right)$ NMR spectra were employed to check the synthesis and purity of the ILs used to carry out the extraction experiments.
The synthesis of the ILs by alkylation of $\mathrm{N}$-methylimidazole using the different alkyl halides was evident from the appearance of the characteristic picks representing each type of $\mathrm{H}$ and $\mathrm{C}$ on their corresponding chemical shifts in the NMR spectra. The appearance of more number of peaks in the up field in the NMR justifies the successful alkylation of N-methylimidazole (Table 3, Figures 1 and 2). 
Table 3. ${ }^{1} \mathrm{H}$ NMR and ${ }^{13} \mathrm{C}$ NMR chemical shifts of the ILs in $\mathrm{CDCl}_{3}$

\begin{tabular}{lll}
\hline IL(Compound) & ${ }^{1} \mathrm{H}$ NMR chemical shift (ppm) & $\begin{array}{l}{ }^{13} \mathrm{C} \text { NMR chemical shift } \\
(\mathrm{ppm})\end{array}$
\end{tabular}

Non $\delta(\mathrm{ppm})=3.52\left(3 \mathrm{H}, \mathrm{s}, \mathrm{CH}_{3}-\mathrm{N}\right), 6.88(1 \mathrm{H}, \mathrm{d}, \mathrm{N}-\mathrm{CH}-$

quaternized $\quad \mathrm{CH}-\mathrm{N}), 7.08(1 \mathrm{H}, \mathrm{d}, \mathrm{N}-\mathrm{CH}-\mathrm{CH}-\mathrm{N}), 7.47(1 \mathrm{H}, \mathrm{s}, \quad \delta(\mathrm{ppm})=30.4,120,130,138$

mim $\mathrm{N}-\mathrm{CH}-\mathrm{N}$ ).

$\left.\left[\mathbf{C}_{4} \mathbf{m i m}\right]\left[\mathbf{P F}_{6}\right] \quad \mathrm{t}, \mathrm{N}-\mathrm{CH}_{2}-\mathrm{CH}_{2}\right), 7.20(1 \mathrm{H}, \mathrm{d}, \mathrm{N}-\mathrm{CH}-\mathrm{CH}-\mathrm{N}), 7.21$

$(1 \mathrm{H}, \mathrm{d}, \mathrm{N}-\mathrm{CH}-\mathrm{CH}-\mathrm{N}), 8.27$ (1H, s, N-CH-N).

$\delta(\mathrm{ppm})=12.97,19.00,31.49$,

$\delta(\mathrm{ppm})=0.70\left(3 \mathrm{H}, \mathrm{t}, \mathrm{CH}_{3}\right), 1.13\left(2 \mathrm{H}, \mathrm{m}, \mathrm{CH}_{2}\right)$,

$1.70\left(2 \mathrm{H}, \mathrm{m}, \mathrm{CH}_{2}\right), 3.72\left(3 \mathrm{H}, \mathrm{s}, \mathrm{CH}_{3}-\mathrm{N}\right), 4.01(2 \mathrm{H}, \quad 35.72,49.45,122.17,123.42$, 135.50

$\delta(\mathrm{ppm})=0.71\left(3 \mathrm{H}, \mathrm{t}, \mathrm{CH}_{3}\right), 1.16\left(6 \mathrm{H}, \mathrm{m}, 3\left(\mathrm{CH}_{2}\right)\right.$, the consecutive three $\mathrm{CH}_{2}$ groups next to the up field $\mathrm{CH}_{3}$ group), $1.72\left(2 \mathrm{H}, \mathrm{m}, \mathrm{CH}_{2}\right), 3.76(3 \mathrm{H}$,

$\left.\left[\mathbf{C}_{6} \mathbf{m i m}\right]\left[\mathbf{P F}_{6}\right] \quad \mathrm{s}, \mathrm{CH}_{3}-\mathrm{N}\right), 4.02\left(2 \mathrm{H}, \mathrm{t}, \mathrm{N}-\mathrm{CH}_{2}-\mathrm{CH}_{2}\right), 7.22(1 \mathrm{H}$, d, N-CH-CH-N), 7.24 (1H, d, N-CH-CH-N), 8.3 $\delta(\mathrm{ppm})=13.37,22.12,25.49$, $29.88,30.80,35.78,43.78$, $122.14,123.48,136.61$ $(1 \mathrm{H}, \mathrm{s}, \mathrm{N}-\mathrm{CH}-\mathrm{N})$

$\delta(\mathrm{ppm})=0.78\left(3 \mathrm{H}, \mathrm{t}, \mathrm{CH}_{3}\right), 1.2(10 \mathrm{H}, \mathrm{m}$, the five consecutive $\mathrm{CH}_{2}$ groups attached with the up field $\mathrm{CH}_{3}$ group), $1.79\left(2 \mathrm{H}, \mathrm{m}, \mathrm{CH}_{2}\right.$ which is attached with the down field $\mathrm{CH}_{2}$, i. e $\left.\mathrm{N}-\mathrm{CH}_{2}\right), 3.82(3 \mathrm{H}, \mathrm{s}$, $\left[\mathbf{C}_{8}\right.$ mim] $\left.]\left[\mathbf{P F}_{6}\right] \quad \mathrm{CH}_{3}-\mathrm{N}\right), 4.05\left(2 \mathrm{H}, \mathrm{t}, \mathrm{N}-\mathrm{CH}_{2}\right), 7.25(1 \mathrm{H}, \mathrm{d}, \mathrm{N}-\mathrm{CH}-$ $\mathrm{CH}-\mathrm{N}), 7.27(1 \mathrm{H}, \mathrm{d}, \mathrm{N}-\mathrm{CH}-\mathrm{CH}-\mathrm{N}), 8.36(1 \mathrm{H}, \mathrm{s}$, $\delta(\mathrm{ppm})=13.97,22.48,26.00$ $28.77,28.89, \quad 29.81, \quad 31.59$, $35.93,49.93,122.18,123.60$, 136.63 $\mathrm{N}-\mathrm{CH}-\mathrm{N})$

$0.814\left(3 \mathrm{H}, \mathrm{t}, \mathrm{CH}_{3}\right.$ up field), $1.23\left(16 \mathrm{H}, 8\left(\mathrm{CH}_{2}\right)\right)$, $1.8\left(2 \mathrm{H}, \mathrm{m}, \mathrm{CH}_{2}\right.$, which is attached to the down $\left[\mathrm{C}_{10} \operatorname{mim}\right]\left[\mathrm{PF}_{6}\right]$ field $\mathrm{CH}_{2}-\mathrm{N}$ group), $3.83\left(3 \mathrm{H}, \mathrm{s}, \mathrm{CH}_{3}-\mathrm{N}\right), 4.07$ $\left(2 \mathrm{H}, \mathrm{t},-\mathrm{N}-\mathrm{CH}_{3}\right), 7.27$ (2H, s, -N-CH-CH-N), 8.38 $(1 \mathrm{H}, \mathrm{s},-\mathrm{N}-\mathrm{CH}-\mathrm{N})$

$\delta(\mathrm{ppm})=14.05,22.82,28.09$, $28.90,29.29,29.31,29.45$, 29.87, 31.81, 35.98, 49.95, $122.19,123.83,138.88$ 

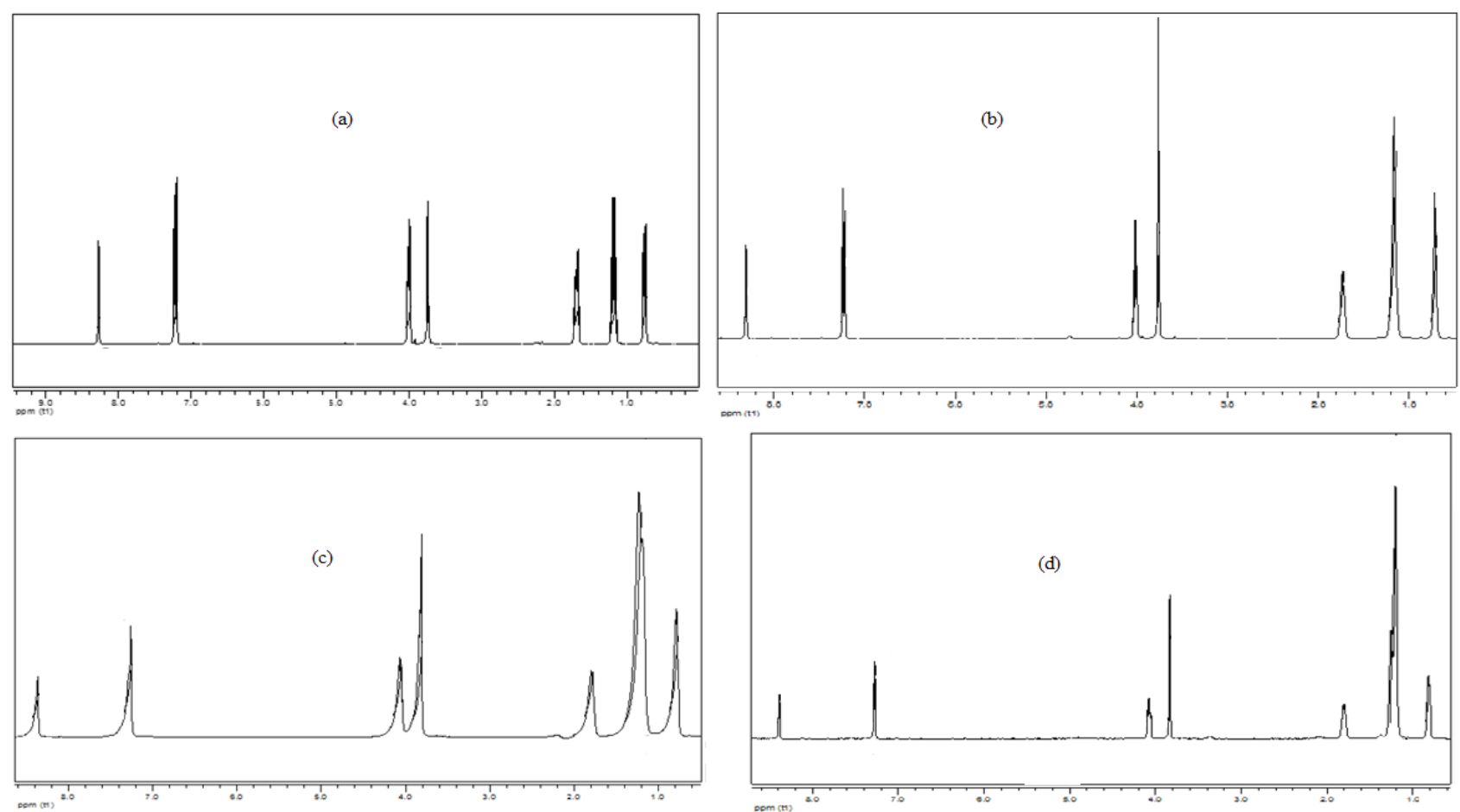

Figure 1. ${ }^{1} \mathrm{H}$ NMR spectrum of (a) $\left[\mathrm{C}_{4} \mathrm{mim}\right]\left[\mathrm{PF}_{6}\right]$, (b) $\left[\mathrm{C}_{6} \mathrm{mim}\right]\left[\mathrm{PF}_{6}\right]$, (c) $\left[\mathrm{C}_{8} \mathrm{mim}\right]\left[\mathrm{PF}_{6}\right],(\mathrm{d})\left[\mathrm{C}_{10} \operatorname{mim}\right]$ $\left[\mathrm{PF}_{6}\right]$
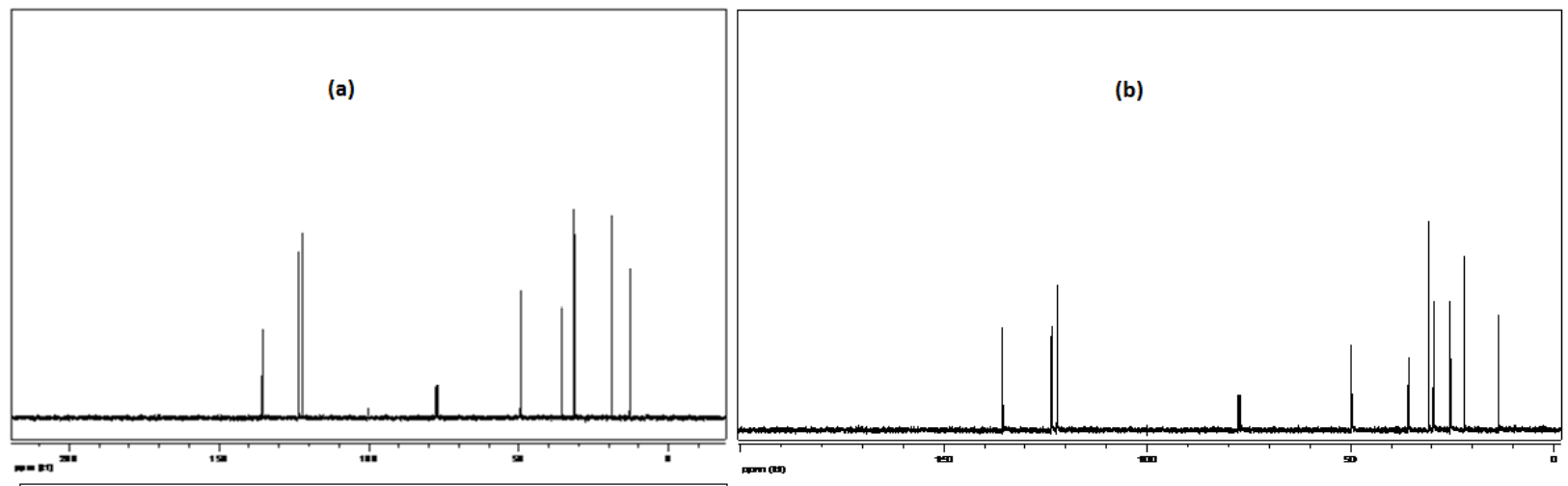

(c)

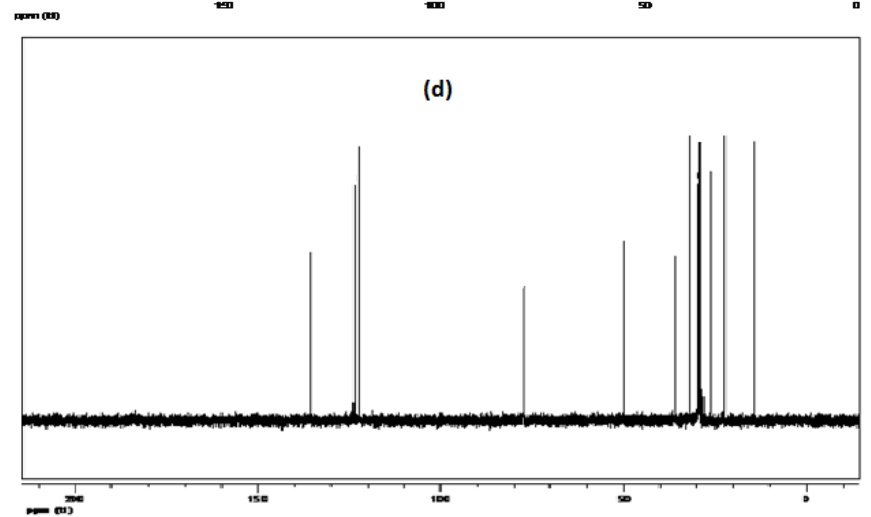

Figure 2. ${ }^{13} \mathrm{C}$ spectrum of $(\mathrm{a})\left[\mathrm{C}_{4} \mathrm{mim}\right]\left[\mathrm{PF}_{6}\right]$, (b) $\left[\mathrm{C}_{6} \mathrm{mim}\right]\left[\mathrm{PF}_{6}\right],(\mathrm{c})\left[\mathrm{C}_{8} \mathrm{mim}\right]\left[\mathrm{PF}_{6}\right],(\mathrm{d})\left[\mathrm{C}_{10} \mathrm{mim}\right]\left[\mathrm{PF}_{6}\right]$ 


\section{Extraction efficiency of the ILs}

The Concentrations of $\mathrm{Cd}^{2+}$ in the aqueous and ILs phases before and after the extraction are indicated in Table 4. The trend of the extraction efficiencies are indicated in Figures 3.

Extraction of $\mathrm{Cd}^{2+}$ from the aqueous phase was achieved using all ionic liquids. Even though $\mathrm{Cd}^{2+}$ is hydrophilic, a good amount was found transferred to the IL phase up on shaking. The metal ions are transferred to the ILs probably being trapped by the cavities in the microstructures of the ILs (Huang et al., 2005). It is also clear that the extraction ability of the ILs increases with the alkyl chain length on the cation (Table 4, Figure $3)$. This is speculated to be due to the increase in the three dimensional cavity size and density as the alkyl chain length increases. For a given IL, better extraction was achieved when the IL to aqueous phase ratio is 1:6 (Table 5) compared to 1:12(Table 4). This may be due to the larger number of cavities in the IL in the former ratio.
However, complete $(100 \%)$ extraction is observed by $\left[\mathrm{C}_{10} \mathrm{mim}\right]\left[\mathrm{PF}_{6}\right]$ from both IL to aqueous phase ratios $(1: 6$ and $1: 12)$ in consistence with the significant increase in the three dimensional cavity density increase following the alkane chain length increase in the cation. Nevertheless, since viscosity is a function of alkane chain length on charge carrying head (Wasserscheid and Welton, 2008), $\left[\mathrm{C}_{10} \mathrm{mim}\right]\left[\mathrm{PF}_{6}\right]$ has the highest viscosity among the ILs tested here and hence limit its ease of application. Previous experiments on extraction of toxic heavy metal ions from aqueous environment showed $\% \mathrm{E}$ as high as $99.3 \%$. This was achieved after employing several modifications including using coordinating molecules Dithizone to lower the hydrophilicity of the metal ion, lowering of $\mathrm{pH}$, modification of the ILs by grafting coordinating appendages on the cation ( Domanska and Rekawek, 2009). Compared with the latter, this work is far cost and time effective.

Table 4. Extraction of $\mathrm{Cd}^{+2}$ at $\mathrm{T}=298 \mathrm{~K}$, using IL to aqueous phase ratio of 1: 12 .

\begin{tabular}{|c|c|c|c|c|c|c|}
\hline \multirow[b]{2}{*}{ ILs } & \multirow{2}{*}{$\begin{array}{l}(\mathrm{Ci})_{\mathrm{aq}} \\
(\mu \mathrm{g} / \mathrm{L})\end{array}$} & \multirow{2}{*}{$\begin{array}{l}(\mathrm{Cf})_{\mathrm{aq}} \\
(\mu \mathrm{g} / \mathrm{L})\end{array}$} & \multirow{2}{*}{$\begin{array}{l}C_{I L} \\
(\mu \mathrm{g} / L)\end{array}$} & \multicolumn{2}{|c|}{$\mathrm{RSD} \%$} & \multirow[b]{2}{*}{$\% \mathrm{E}$} \\
\hline & & & & $(\mathrm{Cf})_{\mathrm{aq}}$ & $\mathrm{C}_{\mathrm{IL}}$ & \\
\hline$\left[\mathrm{C}_{4} \mathrm{mim}\right]\left[\mathrm{PF}_{6}\right]$ & 0.80 & $0.20 \pm 0.002$ & $0.54 \pm 0.0108$ & 1.00 & 2.00 & 75.00 \\
\hline$\left[\mathrm{C}_{6} \mathrm{mim}\right]\left[\mathrm{PF}_{6}\right]$ & 0.80 & $0.13 \pm 0.006$ & $0.63 \pm 0.033$ & 4.61 & 5.23 & 83.75 \\
\hline$\left[\mathrm{C}_{8} \mathrm{mim}\right]\left[\mathrm{PF}_{6}\right]$ & 0.80 & $0.10 \pm 0.0014$ & $0.69 \pm 0.007$ & 1.40 & 1.020 & 87.50 \\
\hline$\left[\mathrm{C}_{10} \mathrm{mim}\right]\left[\mathrm{PF}_{6}\right]$ & 0.80 & $0.0 \pm 0.0$ & $0.80 \pm 0.0220$ & 0.0 & 2.72 & 100.0 \\
\hline
\end{tabular}

Where $(\mathrm{Ci})_{\mathrm{aq}}$ : concentration of the $\mathrm{Cd}^{+2}$ in the aqueous phase before extraction; $(\mathrm{Cf})_{\mathrm{aq}}$ : concentration of the $\mathrm{Cd}^{+2}$ in the aqueous phase after extraction; and $\mathrm{C}_{\mathrm{IL}}$ : concentration of the $\mathrm{Cd}^{+2}$ in the ionic liquid phase 
Table 5. Extraction of $\mathrm{Cd}^{+2}$ at $\mathrm{T}=298 \mathrm{~K}$, using IL to aqueous phase ratio of $1: 6$

\begin{tabular}{|c|c|c|c|c|c|c|}
\hline \multirow[b]{2}{*}{ ILs } & \multirow{2}{*}{$\begin{array}{l}(\mathrm{Ci})_{\mathrm{aq}} \\
(\mu \mathrm{g} / \mathrm{L})\end{array}$} & \multirow{2}{*}{$\begin{array}{l}(\mathrm{Cf})_{\mathrm{aq}} \\
(\mu \mathrm{g} / \mathrm{L})\end{array}$} & \multirow{2}{*}{$\begin{array}{l}C_{\mathrm{IL}} \\
(\mu \mathrm{g} / \mathrm{L})\end{array}$} & \multicolumn{2}{|c|}{ RSD $\%$} & \multirow[b]{2}{*}{$\% \mathrm{E}$} \\
\hline & & & & $(\mathrm{Cf})_{\mathrm{aq}}$ & $\mathrm{C}_{\mathrm{IL}}$ & \\
\hline$\left[\mathrm{C}_{4} \mathrm{mim}\right]\left[\mathrm{PF}_{6}\right]$ & 0.80 & $0.10 \pm 0.0009$ & $0.67 \pm 0.037$ & 0.9 & 5.522 & 87.50 \\
\hline$\left[\mathrm{C}_{6} \mathrm{mim}\right]\left[\mathrm{PF}_{6}\right]$ & 0.80 & $0.00 \pm 0.0$ & $0.79 \pm 0.055$ & 0.0 & 5.696 & 100.0 \\
\hline$\left[\mathrm{C}_{8} \mathrm{mim}\right]\left[\mathrm{PF}_{6}\right]$ & 0.80 & $0.00 \pm 0.0$ & $0.80 \pm 0.009$ & 0.000 & 1.123 & 100.0 \\
\hline$\left[\mathrm{C}_{10} \mathrm{mim}\right]\left[\mathrm{PF}_{6}\right]$ & 0.80 & $0.00 \pm 0.0$ & $0.80 \pm 0.042$ & 0.000 & 5.024 & 100.0 \\
\hline
\end{tabular}

Where $(\mathrm{Ci})_{\mathrm{aq}}$ : concentration of the $\mathrm{Cd}^{+2}$ in the aqueous phase before extraction;

(Cf) ${ }_{\mathrm{aq}}$ : concentration of the $\mathrm{Cd}^{+2}$ in the aqueous phase after extraction; and $\mathrm{C}_{\mathrm{IL}}$ : concentration of the $\mathrm{Cd}^{+2}$ in the ionic liquid phase.

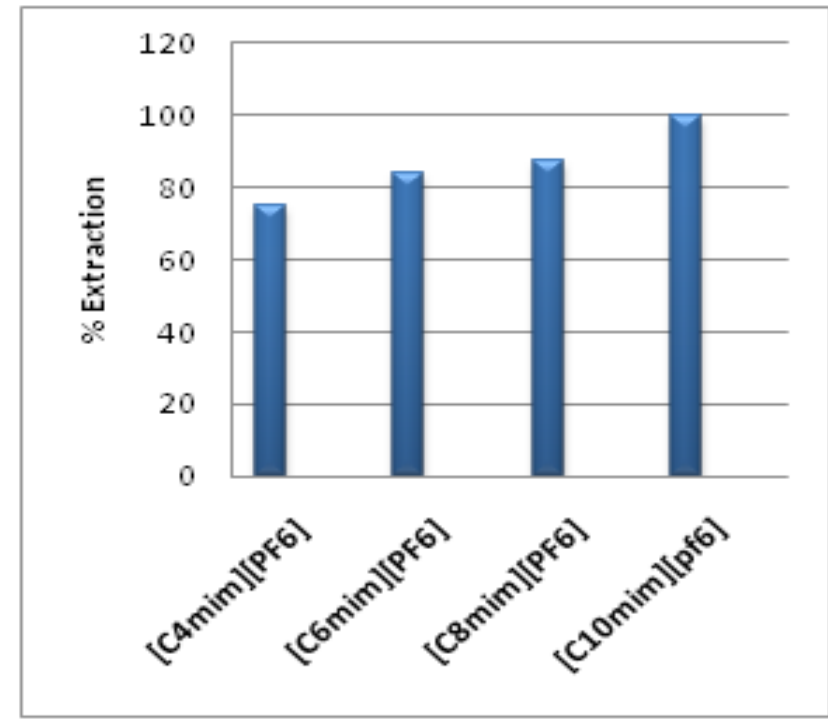

a

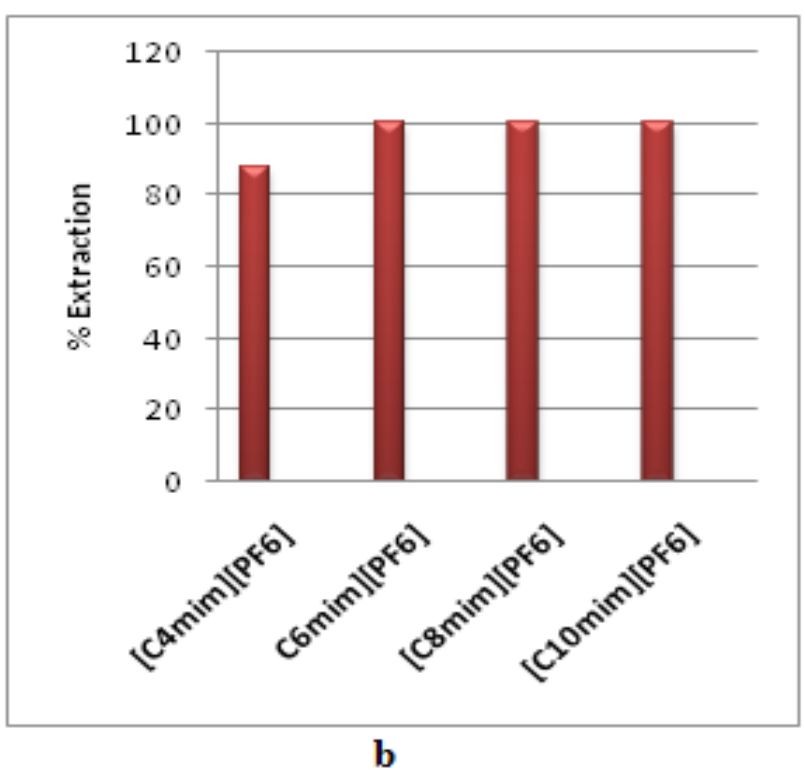

b

Figure 3: Trends of extractions at $298 \mathrm{~K}$, IL to aqueous phase ratio of a) 1:12, b) 1:6

The re-usability of two ILs was tested by recycling five times each. The concentration of $\mathrm{Cd}^{2+}$ before and after the extraction in the aqueous phase for each cycle is indicated in Table 6. The trend of the extraction ability of the ILs for each cycle is showed in Figure 4a-b. The reusability investigations was conducted employing ILs with intermediate alkane chain length ( $\left[\mathrm{C}_{6} \mathrm{mim}\right]\left[\mathrm{PF}_{6}\right]$ and $\left.\left[\mathrm{C}_{8} \mathrm{mim}\right]\left[\mathrm{PF}_{6}\right]\right)$ in order to have a good picture of their reusability. The reusability investigations (Table 6, Figure 4a-b) indicate that ILs can be recycled for reuse in liquid-liquid extraction of metal ions by freeing the cavities where the metal ions are trapped out from the aqueous 
phase. However, the efficiency decreases for each subsequent extraction in all the ILs employed here. This may be due to the interference of $\mathrm{H}^{+}$on the adsorption cavity of the IL from the acid employed to leach the adsorbed $\mathrm{Cd}^{2+}$ from the subsequent solution. For each cycle of extraction in the recyclability experiment, the extraction efficiency is found to increase with the alkyl chain length on the cation. The recovered ionic liquid was reused successively to the same kind of extraction method.

Table 6: The concentration of $\mathrm{Cd}^{2+}$ before and after the extraction in the aqueous phase for each cycle at $298 \mathrm{~K}$ and IL to aqueous phase ratio $1: 6$ of a) $\left[\mathrm{C}_{6} \mathrm{mim}\right]\left[\mathrm{PF}_{6}\right]$, b) $\left[\mathrm{C}_{8} \mathrm{mim}\right]\left[\mathrm{PF}_{6}\right]$

\begin{tabular}{|c|c|c|c|c|c|c|c|c|c|}
\hline \multicolumn{5}{|l|}{$\mathbf{a}$} & \multicolumn{5}{|l|}{ b } \\
\hline Cycle & $\begin{array}{l}(\mathrm{Ci})_{\text {aq }} \\
(\mathrm{mg} / \mathrm{L})\end{array}$ & $\begin{array}{l}(\mathrm{Cf})_{\mathrm{aq}} \\
(\mathrm{mg} / \mathrm{L})\end{array}$ & RSD\% & $\% \mathrm{E}$ & Cycle & $\begin{array}{l}(\mathrm{Ci})^{*}{ }_{\mathrm{aq}} \\
(\mathrm{mg} / \mathrm{L})\end{array}$ & $\begin{array}{l}(\mathrm{Cf})_{\mathrm{aq}}{ }^{* *} \\
(\mathrm{mg} / \mathrm{L})\end{array}$ & RSD\% & $\% \mathrm{E}$ \\
\hline 1 & 1.2 & $0.883 \pm 0.025$ & 2.862 & 26.43 & $\mathrm{~T}$ & 1.2 & $0.767 \pm 0.020$ & 0.263 & 36.13 \\
\hline II & 1.2 & $0.950 \pm 0.037$ & 3.848 & 20.83 & II & 1.2 & $0.839 \pm 0.047$ & 0.556 & 30.09 \\
\hline III & 1.2 & $0.983 \pm 0.035$ & 3.602 & 18.11 & III & 1.2 & $0.846 \pm 0.023$ & 0.275 & 29.49 \\
\hline IV & 1.2 & $1.039 \pm 0.058$ & 5.571 & 13.42 & IV & 1.2 & $0.966 \pm 0.043$ & 0.446 & 19.53 \\
\hline $\mathrm{V}$ & 1.2 & $1.065 \pm 0.036$ & 3.407 & 11.25 & $\mathrm{~V}$ & 1.2 & $1.03 \pm 0.046$ & 0.447 & 14.17 \\
\hline
\end{tabular}

${ }^{*}(\mathrm{Ci})_{\mathrm{aq}}$ : concentration of the $\mathrm{Cd}^{+2}$ in the aqueous phase before extraction; ${ }^{* *}(\mathrm{Cf})_{\mathrm{aq}}$ : concentration of the $\mathrm{Cd}^{+2}$ in the aqueous phase after extraction

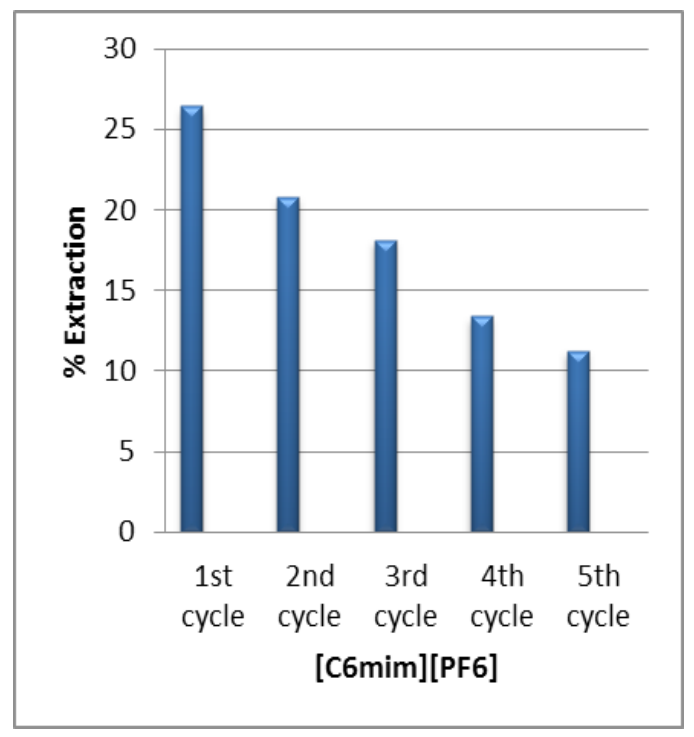

a

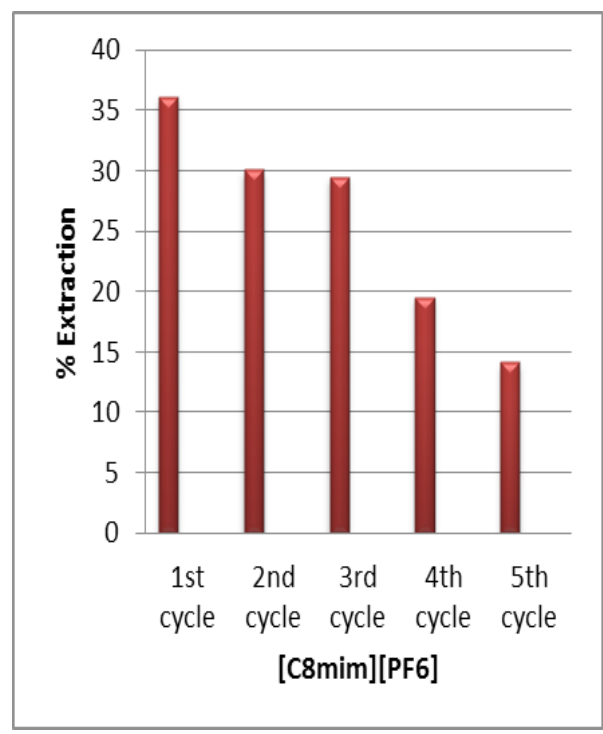

b

Figure 4: Trend of the extraction ability of the ILs at different cycles at $298 \mathrm{~K}$ and IL to aqueous phase ratio $1: 6$ a) $\left[\mathrm{C}_{6} \mathrm{mim}\right]\left[\mathrm{PF}_{6}\right]$, b) $\left[\mathrm{C}_{8} \mathrm{mim}\right]\left[\mathrm{PF}_{6}\right]$ 


\section{CONCLUSION}

The experiment result indicated that merely shaking mixture of very small ionic liquid to aqueous phase ratio as low as 1:12 for an hour is capable of extracting $\mathrm{Cd}^{2+}$ with $75-100 \%$ efficiency from the aqueous phase depending on the alkyl chain length on the cation of the IL. Each IL could extract the metal ion for more than five cycles even though a continuous decrease in the efficiency is observed due to the inability to completely remove the $\mathrm{H}^{+}$used to leach the $\mathrm{Cd}^{2+}$ from each succeeding step. These results demonstrate that ILs are good alternatives in the treatment of polluted water by toxic trace heavy metals such as $\mathrm{Cd}^{2+}$.

\section{ACKNOWLEDGMENTS}

We thank Bahir Dar University for financial support. Sossina Tilahun is thankful to the ministry of education of the Federal Republic of Ethiopia for sponsoring the tuition expenses during her study.

\section{REFERENCES}

Abbott, A.P., Boothby, D., Capper, G., Davies, D.L and Rasheed, R.K. (2004). Deep eutectic solvents formed between choline chloride and carboxylic acids: versatile alternatives to ionic liquids. Journal of the American Chemical Society 126(29):91429147.

Atakilt Abebe, Shimelis Admassie, VillarGarcia, I.J and Yonas Chebude (2013). 4, 4-Bipyridinium ionic liquids exhibiting excellent solubility for metal salts: Potential solvents for electrodeposition. Inorganic Chemistry Communications 29:210-212.

Alonso, M., López-Delgado, A., Sastre, A.M and Alguacil, F.J. (2006). Kinetic modelling of the facilitated transport of cadmium (II) using Cyanex 923 as ionophore. Chemical Engineering Journal 118(3):213-219.

Babel, S and Kurniawan, T.A. (2004). Cr (VI) removal from synthetic wastewater using coconut shell charcoal and commercial activated carbon modified with oxidizing agents and/or chitosan. Chemosphere 54(7): 951- 967.

de los Ríos, A.P., Hernandez-Fernandez, F.J., Lozano, L.J., Sanchez, S., Moreno, J.I and Godinez, C. (2009). Removal of Metal Ions from Aqueous Solutions by Extraction with Ionic Liquids. Journal of Chemical and Engineering Data 55(2):605-608.

Dietz, M.L. (2006). Ionic liquids as extraction solvents: Where do we stand? Separation Science and Technology 41(10):2047-2063.

Domańska, U. and Rękawek A. (2009). Extraction of metal ions from aqueous solutions using imidazolium based ionic liquids. Journal of Solution Chemistry 38(6):739-751.

Earle, M.J and Seddon K.R. (2000). Ionic liquids. Green solvents for the future. Pure and Applied Chemistry 72(7):1391-1398.

El Samrani, A. G., Lartiges, B. S and Villiéras, F. (2008). Chemical coagulation of combined sewer overflow: Heavy metal removal and treatment optimization. Water Research 42(4):951-960. 
Freire, M. G., Santos, L. M.N.B.F., Fernandes, A. M., Coutinho, J.A.P and Marrucho, I. M. (2007). Fluid Phase Equilibria 261:449454.

Fu, F and Wang, Q. (2011). Removal of heavy metal ions from wastewaters: a review. Journal of Environmental Management 92(3):407-418.

Gunatilake, S. K. (2015). Methods of Removing Heavy Metals from Industrial Wastewater. Journal of Multidisciplinary Engineering Science Studies 1(1):12-18.

Hayyan, M., Hashim, M. A., Hayyan, A., AlSaadi, M. A., AlNashef, I. M., Mirghani, M. E and Saheed, O. K. (2013). Are deep eutectic solvents benign or toxic? Chemosphere 90(7):2193-2195.

Hernández-Fernández, F. J., De los Ríos, A. P., Anzola, A. G and Godinez, C. (2010). Use of ionic liquids as green solvents for extraction of $\mathrm{Zn}(2+), \mathrm{Cd}(2+), \mathrm{Fe}(3+)$ and $\mathrm{Cu}(2+)$ from aqueous solutions. Chemical Engineering Transactions 21: 631-636.

Huang, X, Margulis, C.J., Li Y and Berne, B.J. (2005). Why is the partial molar volume of $\mathrm{CO}_{2}$ so small when dissolved in a room temperature ionic liquid? Structure and dynamics of $\mathrm{CO}_{2}$ dissolved in $\left[\mathrm{Bmim}^{+}\right]\left[\mathrm{PF}_{6}^{-}\right.$ ]. Journal of the American Chemical Society 127(50):17842-17851.

Kang, S. Y., Lee, J. U., Moon, S. H and Kim, K. W. (2004). Competitive adsorption characteristics of $\mathrm{Co}^{2+}, \mathrm{Ni}^{2+}$, and $\mathrm{Cr}^{3+}$ by IRN-77 cation exchange resin in synthesized wastewater. Chemosphere 56(2):141-147.

Ku, Y and Jung, I. L. (2001). Photocatalytic reduction of $\mathrm{Cr}$ (VI) in aqueous solutions by UV irradiation with the presence of titanium dioxide. Water Research 35(1):135-142.
Kuo, C.Y and Lin, H.Y. (2009). Adsorption of aqueous cadmium (II) onto modified multiwalled carbon nanotubes following microwave/chemical treatment. Desalination 249:792- 796.

Lancaster, M. (2010). Green chemistry: an introductory text. RSC Publishing, Cambridge, UK, pp340

Landaburu-Aguirre, J., Garcia, V., Pongracz, E and Keiski, R.L. (2000). The removal of zinc from synthetic wastewaters by micellarenhanced ultrafiltration: statistical design of experiments. Desalination 240:262-269

Manahan, S.E. (2011). Fundamentals of environmental chemistry. CRC press, New York. Pp75-114.

Motsi, T., Rowson, N.A and Simmons, M.J. (2009). Adsorption of heavy metals from acid mine drainage by natural zeolite. International Journal of Mineral Processing 92(1):42-48.

Pavasant, P., Apiratikul, R., Sungkhum, V., Suthiparinyanont, P., Wattanachira, S and Marhaba, T. F. (2006). Biosorption of $\mathrm{Cu}^{2+}$, $\mathrm{Cd}^{2+}, \mathrm{Pb}^{2+}$, and $\mathrm{Zn}^{2+}$ using dried marine green macroalga Caulerpa lentillifera. Bioresource Technology 97(18):2321-2329.

Pinto, P.X., Al-Abed, S.R and Reisman, D.J. (2011). Biosorption of heavy metals from mining influenced water onto chitin products. Chemical Engineering Journal 166(3):1002-1009.

Platzer, S., Sap, O., Leyma, R., Wallner, G., Jirsa, F., Kandioller, W., Krachler, R and Keppler, B.K. (2015). Extraction of natural radionuclides from aqueous solutions by novel maltolate-based task-specific ionic liquids. Journal of Radioanalytical and Nuclear Chemistry 303(3):2483-2488. 
Richardson, J.F. and Harker, J.H., (2002), Coulson and Richardson's Chemical Engineering. $5^{\text {th }}$ ed. Butterworth Heinemann, Oxford, UK.pp721-769.

Sereshti, H., Eskandarpour, N., Samadi, S and Aliakbarzadeh, G. (2014). Investigation on Dracaena Sanderiana PhytoremeDiation Ability for $\mathrm{Hg}$ and $\mathrm{Cd}$ using Multivariate Optimized Task Specific Ionic liquid-based Dispersive liquid-liquid Microextraction. International Journal of Environmental Research 8(4):1075-1084.

Villar-Garcia, I.J., Atakilt Abebe and Yonas Chebude. (2012). 1, 10-Phenanthrolinium ionic liquids exhibiting excellent solubility for metal complexes: Potential solvents for biphasic and supported ionic liquid phase (SILP) catalysis Inorganic Chemistry Communications 19:1-3.

Villemin, D and Didi, M.A. (2014). Extraction of rare earth and heavy metals, using ionic solvents as extraction medium (A Review). Oriental Journal of Chemistry 29(4):12671284.

Visser, A.E., Swatloski, R.P., Griffin, S.T., Hartman, D.H and Rogers, R.D. (2001). Liquid/liquid extraction of metal ions in room temperature ionic liquids. Separation Science and Technology 36(5-6):785-804.

Visser, A.E., Swatloski, R.P., Reichert, W.M., Mayton, R., Sheff, S., Wierzbicki, A., Davis, J.H. and Rogers, R.D. Task-specific ionic liquids incorporating novel cations for the coordination and extraction of $\mathrm{Hg}^{2+}$ and $\mathrm{Cd}^{2+}$ : synthesis, characterization, and extraction studies Environmental Science and technology 36(11):2523-2529.
Wang, L.K., Hung, Y.T and Shammas, N.K. (2007). Advanced physicochemical treatment technologies. In: Handbook of Environmental Engineering, vol. 5. Humana, New Jersey. Pp55-106.

Wasserscheid, P and Welton T. (2008). Ionic Liquids in Synthesis; Wiley-VCH: Weinheim, Germany.

Wei, G.T., Yang, Z and Chen, C.J. (2003). Room temperature ionic liquid as a novel medium for liquid/liquid extraction of metal ions. Analytica Chimica Acta 488(2):183192.

Xu, Y., Yang, L and Yang, J. (2010). Removal of cadmium (II) from aqueous solutions by two kinds of manganese coagulants. International Journal of Engineering, Science and Technology 2(7):1-8.

Zhao, H., Xia S and Ma P. (2005). Use of ionic liquids as 'green'solvents for extractions. Journal of Chemical Technology and Biotechnology 80(10):1089-1096. 